\title{
Faktor-Faktor Yang Mempengaruhi Pola Keruangan Belanja Wanita dalam Pemberdayaan Ekonomi di Urban Fringe Kecamatan Sukun Kota Malang
}

\author{
Riska Septina $^{1 *}$, Akhmad Faruq Hamdani ${ }^{1}$, Achmad Maulana Malik Jamil ${ }^{1}$ \\ ${ }^{1}$ Program Studi Pendidikan Geografi Universitas Kanjuruhan Malang, Malang 65148, Indonesia \\ Email: *riskaseptina801@gmail.com, a.faruqhamdani@unikama.ac.id,maulana3188@unikama.com
}

Dikirim : 19 Maret 2019

Diterima: 30 Maret 2019

\begin{abstract}
Abstrak: Kecamatan Sukun merupakan salah satu kecamatan di Kota Malang, sebagai wilayah urban fringe. Perkembangan kota yang terus menerus akan berpengaruh terhadap kegiatan masyarakat yang ada di wilayah urban fringe. Kebiasaan belanja wanita mempunyai pengaruh terhadap pemberdayaan ekonomi dan masyarakat. Pemberdayaan ekonomi berarti memampukan masyarakat sekitar agar mandiri secara ekonomi atau setidaknya memberikan pemacu agar terjadi perkembangan ekonomi di daerah. Penelitian ini bertujuan untuk menganalisis faktor-faktor yang mempengaruhi pola keruangan belanja wanita di urban fringe Kecamatan Sukun Kota Malang. Penelitian ini bersifat deskriptif kuantitatif, dengan teknik pengumpulan data yaitu kuesioner dan dokumentasi. Objek penelitian adalah wanita rumah tangga di urban fringe Kecamatan Sukun Kota Malang. Penentuan sampel didasarkan pada stratified random sampling, dengan jumlah yaitu 100 wanita rumah tangga yang tersebar di enam kelurahan sebagai sampel wilayah. Teknik analisis data yang digunakan yaitu deskriptif persentase, $C h i$ Square dan regresi linear berganda. Hasil penelitian menunjukkan bahwa karakteristik sosial ekonomi wanita di urban fringe Kecamatan Sukun memiliki potensi bagi pemberdayaan ekonomi, ditandai dengan umur yang produktif, tingkat pendidikan, pendapatan dan pengeluaran keluarga. Pola keruangan terutama pada jarak menunjukkan adanya hubungan dengan wilayah urban fringe. Faktor-faktor yang mempengaruhi pola keruangan belanja wanita adalah kepribadian wanita sebagai faktor internal dan sebagai faktor eksternal adalah kualitas serta pilihan produk. Berdasarkan hasil penelitian, maka saran yang diberikan adalah pengembangan sarana dan prasarana di urban fringe Kecamatan Sukun dengan memperhatikan daya saing kualitas dan jumlah produk. Pengembangan fasilitas pelayanan ekonomi terutama pasar tradisional di urban Fringe karena wanita cenderung memilih jarak yang dekat dari tempat tinggalnya untuk belanja.
\end{abstract}

Kata kunci : pola keruangan, belanja wanita, urban fringe

\section{Pendahuluan}

Kecamatan Sukun merupakan salah satu kecamatan di Kota Malang dengan luas wilayah 20,97 km² (Badan Pusat Statistik, 2017: 1). Kecamatan Sukun terdiri dari 11 kelurahan, 6 kelurahan diantaranya berbatasan langsung dengan wilayah Kabupaten Malang yaitu Kelurahan Karang besuki, Kelurahan Pisangcandi, Kelurahan Bandulan, Kelurahan Mulyorejo, Kelurahan Bakalan Krajan dan Kelurahan Kebonsari. Kecamatan Sukun memiliki jumlah penduduk 191.153 Jiwa (Badan Pusat Statistik, 2017: 19).

Daerah pinggiran kota adalah suatu daerah yang juga dikenal sebagai daerah urban fringe merupakan wilayah yang berada di pinggiran kota atau wilayah yang memiliki percampuran sifat antara desa dan kota (Yunus dalam Mahendra 2016:113). Ciri-ciri wilayah urban fringe menurut Yunus (dalam Tappu, 2014: 19) yaitu merupakan wilayah yang berbatasan langsung dengan zona kekotaan, penggunaan lahannya di dominasi bentuk penggunaan lahan perkotaan, lebih dari $60 \%$ berupa urban land use dan kurang dari $40 \%$ rural land use. Berdasarkan ciriciri tersebut, Kecamatan Sukun memiliki wilayah yang termasuk urban fringe dengan rincian penggunaan lahan di Kecamatan Sukun adalah lahan bukan pertanian 1.167 Ha dan penggunaan lahan untuk pertanian $930 \mathrm{Ha}$ (Badan Pusat Statistik, 2017: 55). 
Kota yang semakin padat tidak dapat mengakomodir kebutuhan sehingga berkembang ke wilayah sekitar kota yang dikenal dengan urban fringe (Kusumantoro, 2007). Perkembangan yang terus menerus akan berpengaruh terhadap kegiatan masyarakat yang ada di wilayah urban fringe. Kegiatan belanja wanita yang semakin menyebar dan cenderung berorientasi pada pusat kota akan memberikan pengaruh terhadap pemberdayaan ekonomi. Dalam konteks ini kontribusi wanita didudukan sebagai pelaku kunci yang dapat mendorong perkembangan wilayah sekitar (Indrayanti, 2011:75).

Penelitian ini ingin mengeksplorasi sisi peran wanita dalam pemberdayaan ekonomi, yaitu tentang pola keruangan belanja wanita di daerah pinggiran kota. Peran wanita dalam kegiatan ekonomi perlu ditinjau dari sisi keruangan. Hal ini dikarenakan pola keruangan belanja wanita di wilayah urban fringe akan memberikan pengaruh terhadap pemberdayaan ekonomi. Kebiasaan belanja wanita dari segi pemilihan barang dan lokasi tempat berbelanja mempunyai pengaruh yang sangat besar terhadap pemberdayaan ekonomi dan masyarakat. Pola keruangan wilayah urban fringe Kecamatan Sukun Kota Malang yang berhubungan dengan kawasan permukiman memiliki aksesbilitas seperti sarana transportasi dan jarak akan berpengaruh pada kegiatan belanja wanita dalam pemberdayaan ekonomi.

Kegiatan belanja wanita yang semakin menyebar dan cenderung berorientasi pada luar kecamatan akan memberikan pengaruh terhadap pemberdayaan ekonomi. Dengan adanya pusat perbelanjaan yang memberikan berbagai pilihan fasilitas tempat belanja, yang berada di luar batas administrasi Kecamatan Sukun hal tersebut dapat memberikan pilihan tersendiri bagi wanita dalam memenuhi kebutuhan primer harian keluarganya, apabila dikaitkan dengan karakteristik sosial ekonomi wanita dan jarak tempat tinggal dan lokasi kerja yang dipilih oleh wanita dalam memilih lokasi belanja. Oleh karena itu, tujuan penelitian yaitu menganalisis faktor-faktor yang mempengaruhi pola keruangan belanja wanita dalam pemberdayaan ekonomi di urban fringe Kecamatan Sukun.

\section{Metode Penelitian}

Penelitian ini merupakan penelitian deskriptif dengan pendekatan kuantitatif. Lokasi penelitian berada di enam kelurahan, yaitu: Kelurahan Karang Besuki, Kelurahan Pisang Candi, Kelurahan Bandulan, Kelurahan Bakalan Krajan, dan Kelurahan Kebonsari yang merupakan daerah urban fringe (pinggiran kota) di Kecamatan Sukun Kota Malang. Populasi dalam penelitian ini adalah enam kelurahan di wilayah pinggiran kota Kecamatan Sukun Malang pada tingkatan Rumah Tangga yaitu wanita rumah tangga. Teknik pengampilan sampel data ini disebut stratified random sampling dengan metode pengambilan sampel dengan rumus Solvin menggunakan taraf siginifikansi 10\%. Jumlah sampel dalam penelitian ini berjumlah 100 wanita rumah tangga yang terdapat di enam wilayah dengan memperhatikan besar kecilnya sub-sub populasi.

\section{Pengumpulan data}

\section{Instrumen}

Instrumen yang digunakan dalam penelitian ini adalah kuesioner. Pengumpulan data dalam penelitian ini menggunakan teknik kuesioner dan dokumentasi.

\section{Analisis data}

Teknik analisis data dilakukan dengan cara:

Deskriptif persentase 
Deskriptif persentase, untuk mendeskripsikan umur, tingkat pendidikan, jenis pekerjaan, pendapatan keluarga dan pengeluaran keluarga.

Chi-square

Chi-square digunakan untuk mengetahui hubungan karakteristik sosial ekonomi dengan pola keruangan belanja wanita yang dikelompokan berdasarkan wilayah.

Analisis regresi liner berganda

Analisis regresi liner berganda digunakan untuk menguji hubungan variabel faktor internal dan faktor eksternal terhadap pola keruangan belanja wanita.

\section{Hasil Penelitian dan Pembahasan}

\section{Karakteristik sosial ekonomi wanita urban fringe Kecamatan Sukun Kota Malang}

\section{Umur}

Karakteristik sosial ekonomi wanita di urban fringe yang dicirikan berdasarkan umur, tingkat pendidikan, jenis pekerjaan, pendapatan keluarga dan pengeluaran keluarga yang dimiliki setiap responden berbeda. Hal tersebut sesuai dengan pengertian karakteristik sosial ekonomi yang merupakan ciri-ciri khusus yang menunjukkan seseorang dalam kelompok manusia (Soekanto, 2001). Karakteristik umur sebagian besar pada kategori dewasa (35-55 tahun) sebanyak 49 wanita, kategori muda (21-34 tahun) yaitu 29 wanita, dan kategori tua (> 55 tahun) sebanyak 22 wanita. Berdasarkan hal tersebut diketahui bahwa umur kategori deawasa lebih banyak dibandingkan dengan kategori muda dan tua, akan tetapi karakteristik umur wanita rumah tangga pada batasannya sudah sesuai dengan batasan umur menikah menurut BkkbN yaitu minimal 21 tahun (BkkbN, 2017:1).

\section{Tingkat pendidikan}

Berdasarkan hasil analisis sebagian besar (40\%) responden mempunyai tingkat pendidikan Sekolah Menengah Atas (SMA). Kemudian 24\% responden mempunyai tingkat pendidikan Sekolah Menengah Pertama (SMP). Sedangkan responden yang mempunyai tingkat pendidikan Sekolah Dasar (SD) yaitu 20\%, dan jumlah terendah yaitu tingkat pendidikan Perguruan Tinggi (PT) yaitu $16 \%$ dari jumlah responden.

\section{Jenis pekerjaan}

Berdasarkan hasil penelitian diketahui bahwa 58\% responden bekerja sebagai Ibu Rumah Tangga. Kemudia 29\% responden bekerja sebagai wiraswasta, $3 \%$ responden sebagai Pegawai Negeri Sipil (PNS) dan 10\% menjawab lainnya. Jenis pekerjaan yang banyak dilakukan oleh wanita rumah tangga di urban fringe Kecamatan Sukun Kota Malang yaitu ibu rumah tangga (IRT) yang merupakan tanggung jawab dari seorang wanita. Selain itu wanita di urban fringe Kecamatan Sukun Kota Malang juga bekerja sebagai wiraswasta dan PNS. Hal ini menunjukkan bahwa wanita di urban fringe Kecamatan Sukun memiliki tugas dan tanggung jawab masing-masing. Hal ini sesuai dengan pengertian pekerjaan yang merupakan sekumpulan tugas dan tanggung jawab yang akan, sedang dan telah dikerjakan dalam kurun waktu tertentu (Sastrohardiwiryo, 2003: 127). 


\section{Pendapatan keluarga}

Gambaran tentang pendapatan keluarga berdasarkan hasil penelitian adalah sebagai berikut:

Tabel 1 Distribusi pendapatan keluarga

\begin{tabular}{clc}
\hline No & \multicolumn{1}{c}{ Pendapatan } & Persentase (\%) \\
\hline 1 & Rp 0 - Rp1.000.000 & 33 \\
2 & Rp. $1.000 .001-$ Rp. 2.000 .000 & 35 \\
3 & Rp. 2.000.001-Rp. 3.000.000 & 17 \\
4 & Rp. 3.000.001-Rp. 4.000.000 & 11 \\
5 & Rp. 4.000.001-Rp. 5.000.000 & 2 \\
6 & $>$ Rp. 5.000.001 Jumlah & 2 \\
& \multicolumn{1}{c}{ Jum } \\
\hline
\end{tabular}

Sumber: Data Penelitian diolah, 2018

Pendapatan keluarga yang dimiliki dapat dilihat dari siapa saja yang bekerja dan jenis pendapatan yang diterima. Anggota keluarga yang bekerja dalam satu keluarga sebagian besar didominasi oleh suami saja. Jenis pendapatan sebagian besar dari pendapata pokok saja. Hal ini sesuai dengan pendapat BPS tentang pendapatan keluarga atau rumah tangga yang merupakan pendapatan yang diterima oleh rumah yang bersangkutan yang berasal dari pendapatan kepala keluarga maupun anggota keluarga rumah tangga (BPS, 2018:7).

\section{Pengeluaran keluarga}

Pengeluaran keluarga wanita di wilayah urban fringe Kecamatan Sukun secara jelas digambarkan pada tabel 2 berikut:

Tabel 2 Pengeluaran keluarga

\begin{tabular}{ccc}
\hline No & \multicolumn{1}{c}{ Pengeluaran } & Persentase (\%) \\
\hline 1 & Rp 0 - Rp1.000.000 & 30 \\
2 & Rp.1.000.001 - Rp. 2.000.000 & 43 \\
3 & Rp. 2.000.001 - Rp. 3.000.000 & 21 \\
4 & Rp. 3.000.001 - Rp. 4.000.000 & 4 \\
5 & Rp. 4.000.001 - Rp. 5.000.000 & 1 \\
6 & $>$ Rp. 5.000.001 Jumlah & 1 \\
& \multicolumn{100}{c}{ Jut } \\
\hline
\end{tabular}

Sumber: Data Penelitian diolah, 2018

Jenis pendapatan sebagian besar dari pendapata pokok saja. Hal ini sesuai dengan pendapat BPS tentang pendapatan keluarga atau rumah tangga yang merupakan pendapatan yang diterima oleh rumah yang bersangkutan yang berasal dari pendapatan kepala keluarga maupun anggota keluarga rumah tangga (BPS, 2018:7).

Pengeluaran keluarga per bulan sebagian besar berada pada angka Rp. 1.000.001Rp.2.000.000 per bulan dengan jenis pengeluaran paling banyak tiga jenis pengeluaran yaitu kebutuhan pokok, biaya sekolah dan juga tabungan. Hal tersebut sesuai dengan pengertian pengeluaran yang merupakan biaya konsumsi rumah tangga untuk barang atau jasa yang diperoleh secara pembelian oleh rumah tangga (Oktama, 2013:20). Berdasarkan hal tersebut diketahui bahwa biaya konsumsi (barang dan jasa) yang dikeluarkan dalam belanja dilakukan untuk pemenuhan kebutuhan pokok juga kebutuhan kesehatan dan biaya sekolah. 


\section{Pola keruangan belanja wanita Kecamatan Sukun Kota Malang}

Pada analisis pola keruangan belanja diketahui terdapat tiga hal yaitu jarak (penarikan jarak tempat tinggal responden terhadap tempat belanja yang dipilih), lokasi belanja, dan lokasi kerja, ketiganya dihubungkan dengan wilayah urban fringe Kecamatan Sukun Kota Malang. Untuk mengetahui ada atau tidaknya hubungan pola keruangan dengan wilayah, maka ditentukan hipotesis yaitu:

$\mathrm{H}_{0}=$ Tidak terdapat hubungan antara pola keruangan belanja wanita dengan wilayah urban fringe di Kecamatan Sukun Kota Malang.

$\mathrm{H}_{1}=$ Terdapat hubungan antara pola keruangan belanja wanita dengan wilayah urban fringe di Kecamatan Sukun Kota Malang.

Taraf signifikansi yang digunakan adalah $10 \%$, berdasarkan probabilitas jika $\mathrm{p}>0,10$ maka $\mathrm{H}_{0}$ diterima dan jika $\mathrm{p}<0,10$ maka $\mathrm{H}_{0}$ ditolak. Untuk lebih jelasnya akan diuraikan sebagai berikut:

\section{Jarak}

Berdasarkan hasil analisis diketahui bahwa jarak memiliki hubungan dengan wilayah urban fringe. Hal ini dibuktikan dengan hasil analisis Chi Square yang menunjukan bahwa $\mathrm{p}<0,10$, dapat dilihat pada tabel 5.3 berikut:

Tabel 3 Hasil perhitungan chi square antara jarak dengan wilayah

\begin{tabular}{lc}
\hline & Asymp. Sig. (2-sided) \\
\hline Pearson Chi-Square & .017 \\
Likelihood Ratio & .002 \\
Linear-by-Linear Association & .468 \\
N of Valid Cases & \\
\hline Sumber: Data output SPSS 22 diolah, 2018 &
\end{tabular}

Pola keruangan di wilayah urban fringe Kecamatan Sukun Kota Malang dapat etrbentuk dari penarikan jarak tempat tinggal responden terhadap tempat belanja yang dipilih. Hal tersebut sesuai dengan pendapat Yustriany (2012:16) bahwa jarak dikenal dari usaha kita bergerak dari satu tempat ke tempat lain dan dikenali dari isyarat lingkungan untuk prospek visual.

\section{Lokasi belanja}

Lokasi belanja wanita merupakan tempat yang dipilih wanita responden untuk membeli barang dalam memenuhi kebutuhan keluarganya. Berdasarkan hasil penelitian, bahwa tidak terdapat hubungan antara lokasi belanja wanita dengan wilayah urban fringe di Kecamatan Sukun Kota Malang. Hal ini dibuktikan dengan hasil perhitungan Chi Square yang menunjukkan bahwa $\mathrm{p}>0,10$ yang terdapat pada tabel 5.4 berikut:

Tabel 4 Hasil perhitungan chi Square antara lokasi belanja dengan wilayah

\begin{tabular}{lc} 
& Asymp. Sig. (2-sided) \\
\hline Pearson Chi-Square & .890 \\
Likelihood Ratio & .893 \\
Linear-by-Linear Association & .965 \\
N of Valid Cases & \\
\hline Sumber: Data output SPSS 22 diolah, 2018
\end{tabular}

Sumber: Data output SPSS 22 diolah, 2018 
Berdasarkan hasil Chi Square diketahui bahwa nilai Asymp Sig $0.890>0.10$ maka $\mathrm{H}_{0}$ diterima, artinya tidak ada hubungan antara lokasi belanja dengan wilayah Urban fringe. Akan tetapi pada lokasi belanja dapat diketahui distribusi kegiatan belanja wanita yang sebagian besar $41 \%$ memilih belanja di pasar tradisional, $39 \%$ belanja di kios dan $20 \%$ belanja di pasar modern/mall.

\section{Lokasi Kerja}

Lokasi kerja merupakan tempat wanita bekerja yang dilihat dari wilayah mereka bekerja, antara lain di sekitar permukiman, satu kecamatan dan di luar kecamatan. Berdasarkan hasil analisis Chi square dengan menggunakan aplikasi SPSS IBM 22 for windows diketahui bahwa tidak ada hubungan antara lokasi kerja dengan wilayah. Hal ini dibuktikan dengan nilai $\mathrm{p}>$ 0,10 yang dapat dilihat pada tabel berikut:

Tabel 5 Hasil perhitungan chi Square antara Lokasi Kerja dengan Wilayah

\begin{tabular}{lc}
\hline & Asymp. Sig. (2-sided) \\
\hline Pearson Chi-Square & .977 \\
Likelihood Ratio & .965 \\
Linear-by-Linear Association & .719 \\
N of Valid Cases & \\
\hline
\end{tabular}

Sumber: Data output SPSS 22 diolah, 2018

Distribusi lokasi kerja wanita rumah tangga sebagian besar $45 \%$ bekerja di sekitar pemukiman, $31 \%$ bekerja di satu kecamatan dan $24 \%$ bekerja di luar kecamatan. Berdasarkan kedua hal tersebut (lokasi belanja dan lokasi kerja) dapat diketahui distribusi kegiatan wanita di urban fringe cenderung berada di wilayah masing-masing seperti belanja di kios dan bekerja di sekitar permukiman. Hal ini sesuai dengan teori lokasi yang berusaha menjelaskan distribusi kegiatan di suatu tempat (Suryani, 2015:154).

Pola keruangan belanja wanita di urban fringe Kecamatan Sukun Kota Malang diketahui sebagian besar pada jarak $<1 \mathrm{~km}$ dari tempat tinggalnya, belanja di pasar tradisional dan kios, serta bekerja disekitar permukiman yang sebagian besar wanita rumah tangga memilih lokasi belanja dengan jarak $<1 \mathrm{~km}$ dari tempat tinggalnya merupakan kekhasan sebaran belanja wanita di urban fringe. Hal ini sejalan dengan pendapat Yunus (2010:50) yaitu pola keruangan merupakan kekhasan sebaran keruangan gejala geosfer di permukaan bumi.

Kekhasan sebaran pola keruangan belanja wanita yang diukur dengan jarak, lokasi belanja dan lokasi kerja berdasarkan wilayah diketahui terdapat beberapa kelurahan yang memiliki perbedaan. Perbedaan tersebut dikarenakan karakteristik sosial ekonomi wanita rumah tangga terutama pada pendapat keluarga setiap bulan. Kelurahan Mulyorejo dan Kelurahan Pisangcandi memiliki penghasilan yang bervariasi dari kisaran antara Rp. 0-Rp. 1.000.000 sampai dengan > Rp. 5.000.000, sebagian besar wanita yang memilih lokasi belanja di pasar tradisional, dengan jarak $<1 \mathrm{~km}$ dari tempat tinggal wanita rumah tangga, dan bekerja di sekitar pemukiman. Sedangkan pada Kelurahan Bakalankrajan memiliki penghasilan antara Rp. 0-Rp. 1.000.000 sampai dengan Rp. 1.000.001- Rp. 2.000.000, sebagian besar wanita rumah tangga memilih kios sebagai tempat belanja mereka, dengan jarak antara 4- 5,9 km dari lokasi tempat tinggal mereka.

\section{Faktor-Faktor yang Mempengaruhi Pola Keruangan Belanja Wanita}

Faktor-faktor yang mempengaruhi pola keruangan belanja wanita dianalisis dengan menggunakan analisis regresi linear berganda. untuk mengetahui pengaruh faktor internal (gaya 
hidup, kepribadian, dan motivasi) dan faktor eksternal (Harga, Produk dan Pelayanan) terhadap pola keruangan belanja wanita rumah tangga di wilayah urban fringe.

\section{Faktor internal}

Faktor internal dalam penelitian ini yaitu gaya hidup, kepribadian, dan motivasi wanita rumah tangga dalam kegiatan belanja. Untuk mengetahui apakah faktor internal berpengaruh terhadap pola keruangan belanja wanita maka dilakukan pengujian regresi linear berganda dengan rumusan hipotesis sebagai berikut:

$\mathrm{H}_{0}=$ Faktor-faktor internal tidak berpengaruh terhadap pola keruangan belanja wanita.

$\mathrm{H}_{1}=$ Faktor-faktor internal berpengaruh terhadap pola keruangan belanja wanita.

Taraf signifikansi yang digunakan adalah $10 \%$ berdasarkan nilai probabilitas jika $p>0.10$ maka $\mathrm{H}_{0}$ diterima dan jika $\mathrm{p}<0.10$ maka $\mathrm{H}_{0}$ ditolak. Persamaan regresi dapat dilihat dari tabel hasil uji coefisient berdasarkan output SPPS terhadap pengaruh variabel faktor-faktor yang mempengaruhi pola keruangan belanja pada faktor internal yaitu gaya hidup, kepribadian, dan motivasi terhadap pola keruangan belanja wanita yang ditunjukkan pada tabel 5.6 sebagai berikut:

Tabel 6 Hasil analisis regresi linear berganda faktor internal

\begin{tabular}{ll}
\hline Model & Sig. \\
\hline (Constant) & .000 \\
Gaya Hidup & .121 \\
Kepribadian & .093 \\
Motivasi & .358 \\
\hline Sumber: Data output SPSS 22 diolah, 2018
\end{tabular}

Berdasarkan tabel 4 di atas dapat diketahui nilai probabilitas setiap variabel, selain itu menunjukkan bahwa variabel kepribadian saja yang berpengaruh terhadap pola keruangan belanja wanita di urban fringe Kecamatan Sukun Kota Malang dengan nilai signifikansi 0.10, adalah sebagai berikut:

Nilai konstanta

Nilai konstanta sebesar $0.000<0.10$, hal ini menunjukkan faktor internal (gaya hidup, kepribadian dan motivasi) berpengaruh terhadap pola keruangan belanja wanita wanita di urban fringe Kecamatan Sukun Kota Malang. Bila faktor internal naik atau berpengaruh dalam satu satuan, maka akan berpengaruh terhadap pola keruangan belanja wanita akan naik atau terpenuhi.

Pengaruh kepribadian terhadap pola keruangan belanja wanita

Pada variabel kepribadian diketahui bahwa nilai $\mathrm{p}$ adalah $0.093<0.10$, dengan demikian $\mathrm{H}_{0}$ ditolak dan $\mathrm{H}_{1}$ diterima. Artinya variabel kepribadian berpengaruh terhadap pola keruangan belanja wanita.

Pengaruh gaya hidup terhadap pola keruangan belanja wanita

Berdasarkan nilai probabilitas, variabel gaya hidup adalah $0.121>0.10$, dengam demikian $\mathrm{H}_{0}$ diterima. Artinya bahwa variabel gaya hidup tidak berpengaruh terhadap pola keruangan belanja wanita.

Pengaruh motivasi terhadap pola keruangan belanja wanita

Berdasarkan nilai probabilitas, variabel motivasi adalah $0.358>0.10$, dengam demikian $\mathrm{H}_{0}$ diterima. Artinya bahwa variabel motivasi tidak berpengaruh terhadap pola keruangan belanja wanita. 


\section{Faktor eksternal}

Faktor eksternal dalam penelitian ini yaitu harga, produk dan pelayanan. Untuk mengetahui apakah faktor eksternal berpengaruh terhadap pola keruangan belanja wanita, maka dilakukan pengujian regresi linear berganda. Dengan rumusan hipotesis sebagai berikut:

$\mathrm{H}_{0}=$ Faktor-faktor Eksternal (harga, produk, dan pelayanan) tidak berpengaruh terhadap pola keruangan belanja wanita.

$\mathrm{H}_{1}=$ Faktor- faktor Eksternal (harga, produk, dan pelayanan) berpengaruh terhadap pola keruangan belanja wanita.

Taraf signifikansi yang digunakan adalah $10 \%$ berdasarkan nilai probabilitas jika $p>0.10$ maka $\mathrm{H}_{0}$ diterima dan jika $\mathrm{p}<0.10$ maka $\mathrm{H}_{0}$ ditolak. Persamaan regresi dapat dilihat dari tabel hasil uji coefisient berdasarkan output SPPS terhadap pengaruh variabel faktor-faktor yang mempengaruhi pola keruangan belanja pada faktor ekstrenal yaitu harga, produk, dan pelayanan terhadap pola keruangan belanja wanita yang ditunjukkan pada tabel 5.7 sebagai berikut:

Tabel 7 Hasil analisis regresi linear berganda faktor eksternal

\begin{tabular}{|c|c|}
\hline Model & Sig. \\
\hline 1 (Constant) & .000 \\
\hline Harga & .730 \\
\hline Produk & .045 \\
\hline Pelayanan & .505 \\
\hline
\end{tabular}

Sumber: Data output SPSS 22 diolah, 2018

Berdasarkan tabel 7 di atas dapat diketahui nilai probabilitas setiap variabel, bahwa variabel produk saja yang berpengaruh terhadap pola keruangan belanja wanita di urban fringe Kecamatan Sukun Kota Malang dengan nilai signifikansi 0.10, adalah sebagai berikut:

Nilai konstanta

Nilai konstanta sebesar $0.000<0.10$, nilai konstanta positif menunjukkan pengaruh positif faktor eksternal (harga, produk dan pelayanan) terhadap pola keruangan belanja wanita wanita di urban fringe Kecamatan Sukun Kota Malang.

Pengaruh produk terhadap pola keruangan belanja wanita

Pada variabel produk diketahui bahwa nilai p adalah $0.045<0.10$, dengan demikian $\mathrm{H}_{0}$ ditolak dan $\mathrm{H}_{1}$ diterima. Artinya variabel produk berpengaruh terhadap pola keruangan belanja wanita.

Pengaruh harga terhadap pola keruangan belanja wanita

Variabel harga diketahui bahwa nilai probabilitasnya adalah $0.730>0.10$, dengam demikian $\mathrm{H}_{0}$ diterima. Artinya bahwa secara parsial variabel harga tidak berpengaruh terhadap pola keruangan belanja wanita.

Pengaruh pelayanan terhadap pola keruangan belanja wanita

Berdasarkan nilai probabilitas, variabel pelayanan adalah $0.505>0.10$, dengam demikian $\mathrm{H}_{0}$ diterima. Artinya bahwa variabel pelayanan tidak berpengaruh terhadap pola keruangan belanja wanita. Koefisien determinasi merupakan besaran (nilai) yang menunjukkan besarnya variasi variabel pola keruangan belanja wanita yang dapat dijelaskan oleh harga, produk, dan pelayanan.

Faktor-faktor yang mempengaruhi belanja wanita terdiri dari faktor internal dan faktor eksternal. Berdasarkan hasil analisis diketahui bahwa faktor internal gaya hidup dan motivasi tidak berpengaruh terhadap pola keruangan belanja wanita dan yang berpengaruh terhadap pola keruangan belanja wanita adalah kepribadian. Kepribadian wanita rumah tangga yang berbeda dalam menyikapi pemenuhan kebutuhan keluarga berbeda-beda. Hal tersebut sesuai dengan 
yang dimaksudkan Yustiany (2012:23) bahwa kepribadian adalah ciri-ciri psikologis yang membedakan seseorang. Secara keseluruhan faktor internal memiliki sumbangan pengaruh terhadap pola keruangan belanja wanita yang dapat dilihat dari nilai koefisien determinasinya.

Berdasarkan hasil analisis pada faktor eksternal (harga, produk, pelayanan). Pada faktor eksternal harga dan pelayanan tidak memiliki pengaruh pada pola keruangan belanja wanita, akan tetapi produk berpengaruh terhadap pola keruangan belanja wanita. Hal ini sesuai dengan pendapat Kotler (dalam Hariyadi, 2016:18) bahwa produk adalah segala sesuatu yang ditawarkan pasar untuk memuaskan keinginan dan kebutuhan. Wanita rumah tangga di urban fringe Kecamatan Sukun Kota Malang sebagian besar 49\% produk dengan kualitas barang bagus pilihan barang banyak, harga murah sebanyak 52\% dan 50\% memilih pelayanan penjual ramah. Hal ini dapat disimpulkan bahwa wanita di urban fringe membeli suatu produk untuk memuaskan keinginannya.

Faktor internal dan eksternal secara keseluruhan masih memiliki sumbangan pengaruh terhadap pola keruangan belanja wanita di urban fringe Kecamatan Sukun Kota Malang. Dengan demikian faktor internal dan eksternal dapat mempengaruhi pola keruangan belanja wanita. Hal tersebut sesuai dengan pendapat Kolter dan Keller yaitu ada faktor internal dan eksternal memengaruhi konsumen dalam mengambil keputusan dalam belanja (Medina, 2017: 528).

\section{Kesimpulan}

Berdasarkan hasil penelitian dan pembahasan yang telah dilakukan, maka dapat disimpulkan bahwa karakteristik sosial ekonomi wanita berdasarkan umur sebagian besar adalah umur dewasa (34-55), pendidikan terakhir SMA dengan jenis pekerjaan sebagian besar menjadi ibu rumah tangga. Penghasilan keluarga setiap bulan dengan pengeluaran keluarga setiap bulan berada pada kisaran angka yang sama yaitu antara Rp. 1.000.001-Rp.2.000.000 dengan pengeluaran paling banyak untuk kebutuhan pokok, biaya sekolah, dan kesehatan.Pola keruangan yang terbentuk adalah kekhasan sebaran berdasarkan jarak, sebagian besar wanita di urban fringe memilih belanja di tempat dengan jarak $<1 \mathrm{~km}$ sebesar 52\%, meskipun lokasi belanja tidak memiliki hubungan dengan wilayah urban fringe akan tetapi wanita di urban fringe sebagian besar $41 \%$ memilih belanja di pasar tradisional dan bekerja di sekitar pemukiman sebesar $45 \%$. Hal ini menunjukkan bahwa wanita di urban fringe ikut berperan dalam pemberdayaan ekonomi. Faktor-faktor yang mempengaruhi pola keruangan belanja wanita di urban fringe, dipengaruhi oleh kepribadian setiap wanita di urban fringe memiliki cara yang berbeda dalam menyikapi kebutuhan yang akan dibeli. Faktor eksternal yaitu produk yang mempengaruhi pola keruangan belanja, wanita di urban fringe menjadikan produk sebagai bahan pertimbangan pemilihan lokasi belanja. Bagi peneliti selanjutnya diharapkan untuk mempersiapkan kuesioner yang mendalam dan membandingkan dengan penelitian terdahulu sehingga menghasilkan penelitian yang lebih baik lagi.

\section{Ucapan Terimakasih}

Peneliti menyadari bahwa penyelesaian artikel ini tidak lepas dari bantuan berbagai pihak, oleh karena itu peneliti mengucapkan terimakasih kepada Universitas Kanjuruhan Malang sebagai lembaga pendidikan untuk peneliti menuntut ilmu. Wanita rumah tangga di wilayah urban fringe Kecamatan Sukun Kota Malang yang bersedia memberikan waktu dan informasinya kepada peneliti. 


\section{Daftar Rujukan}

BkkbN. 2017. BkkbN: Usia Pernikahan Ideal 21 dan 25 Tahun. (Online), (http://www.bkkbn.go.id), diakses 22 September 2018.

BPS. 2017. Kecamatan Sukun Dalam Angka 2017. (Online) (https://malangkota.bps.go.id/), diakses 25 Juni 2018

Hariyadi, Guruh Taufan. 2016. Faktor-Faktor yang mempengaruhi Konsumen berbelanja di Minimarket (Studi Pada Indomaret dan Alfamart di Semarang). Jurnal Penelitian Ekonomi dan Bisnis, 1(1): 16-32. (Online), (http://www.jpeb.dinus.ac.id), diakses 18 September 2018

Indrayati, Ariyani. 2010. Peran Wanita Dalam Pemberdayaan Ekonomi Lokal (Studi Kasus Tentang Pola Ruang Belanja Wanita DI Daerah Pinggiran Kota Semarang). Geografi FIS UNNES. Jurnal Geografi, 7(2): 88-102.

Kusumantoro, I. P. (2007). Menggagas Bentuk Ruang Kota Alternatif: Upaya Mereduksi Intensitas Pergerakan Lalu Lintas Kota. Jurnal Perencanaan Wilayah dan Kota, 18 (3): 78-90.

Mahendra, yusril Ihza dan Wisnu Pradoto. 2016. Transformasi Spasial di Kawasan Peri Urban Kota Malang. Jurnal Pembangunan Wilayah \& Kota, 12 (1): 112-126. (Online) (ejournal.undip.ac.id), diakses 4 September 2018.

Medina, Rd. Ajeng Adistya. 2017. Pola Spasial Pemilihan Lokasi Belanja Kebutuhan Primer Penduduk Kecamatan Bogor Tengah. Industrial Research Workshop and National Seminar. (Online), (https://jurnal.polban.ac.id), diakses 9 September 2018

Sastrohadiwirya, Siswanto. 2003. Manajemen Tenaga kerja Indonesia Pendekatan Administratif dan Operasional. Jakarta: Bumi Aksara.

Suryani, Yosi. 2015. Teori Lokasi Dalam Penentuan Pembangunan Lokasi Pasar Tradisional (Telaah Studi Literatur). Seminar Nasional Ekonomi Manajemen Dan Akuntansi (Snema) Fakultas Ekonomi Universitas Negeri Padang, (152-163). (Online), (http://fe.unp.ac.id/), diakses 18 September 2018.

Tappu, Andi Tenri. 2014. Analisis Pengaruh Transformasi Spasial Terhadap Pemanfaatan Lahan Pertanian di Kawasan Pesisir Peri Urban Kota Makassar (Studi Kasus Kelurahan Barombang). Skripsi Fakultas Sains dan Teknologi Prodi Perencanaan Wilayah dan Kota UIN ALAUDDIN MAKASSAR. (Online). (http://repositori.uinalauddin.ac.id), diakses 28 September 2018.

Yustianty, Avrie. 2012. Pola Keruangan Yang Terbentuk Pada Proses Belanja Online (Studi Kasus di Kota Depok). Skripsi Fakultas MIPA Prodi Geografi UI. (Online), (lib.ui.ac.id), diakses 12 Agustus 2018 